\title{
The significant Causes and effects of delays in Ghadir 2206 residential project
}

\author{
${ }^{1}$ Ebrahim Aboutorabi Najafabadi, ${ }^{2}$ Prof. Dr. S. S. Pimplikar, \\ ${ }^{1}$ Research Graduate ME (Construction \& Management) \\ ${ }^{2}$ Professor \& Head-Civil Department MIT-Pune
}

\begin{abstract}
Delays in the construction projects are global events and the construction industry in Iran is no exception. The main purpose of this study is to identify the delay factors and their effect on a particular project completion named Ghadir 2206 residential construction project located in Fooladshahr, Iran.

It is attempted to analyze the most important causes and their impacts on specific effects.

This study identified nine most important causes of delay and effects of delay. Nine most important causes were: 1) Contractor's improper planning, 2) Design changes, 3) Contractor's poor site management and mistaken decision in changing managers, 4) Inadequate contractor experience, 5) Inadequate client's finance and payments for completed work, 6) Problems with subcontractors, 7) Lack of communication between parties, 8) Construction mistakes and defective works, 9) Material price escalation. The causes categories in contractorrelated factors, consultant-related factors, client-related factors and external factors.

The high significant causes identified are 1) Design changes 2) Material price escalation
\end{abstract}

Six main effects of delay were:

1) Time overrun 2) Cost overrun, 3) Disputes, 4) Arbitration, 5) Litigation, and 6) Abandonment

Keywords: Delay causes; Delay effects; Construction industry; Iran; Ghadir 2206 residential project;

\section{Introduction}

Delays are insidious often resulting in time overrun, cost overrun, disputes, litigation, and complete abandonment of projects (Sambasivan and Soon, 2007).

Many projects are of such a nature that the client will suffer hardship, expense, or loss of revenue if the work is delayed beyond the time specified in the contract (Clough, 1986). Then again, delay has cost consequences for the contractor.

Delay is a reality in the construction process in the world. Although there may be unique aspects of the different projects, sites, contract terms and customs and practices in different parts of the world, for the most part the reality of delay unfortunately is universal to the construction industry.

In construction claims, the term "delay" is used to mean two different but related matters. Delay is often used to mean the time period during which some part of the construction project has been extended beyond what was originally planned due to unanticipated circumstances. Extension beyond what was initially planned may also be called prolongation. Delay can also be the incident that affects the performance of a particular activity, with or without affecting project completion. This concept of postponement occurs when the planned start of an activity or project is delayed. An incident delay can originate from within the contractor's organization or from any of the other factors interacting with the construction project. Incidences of delay from within the contractor's organization are essentially those occurrences that the contractor himself has caused or for which he is legally responsible.

Incidences outside of the contractor's organization may be caused by the owner (or employer) the designer, other prime contractors, subcontractors, suppliers, labor unions, nature, or any of a number of other organizations and entities that participate in the construction process.

Many events may occur on the construction project to increase the time of performance of the overall project or affect any given activity. The most common causes of delay are contractor management and performance problems; differing site conditions; changes in requirements or design; inclement weather; unavailability of labor, material, or equipment; defective plans and specifications; and owner interference. These and other delays not only increase the time required to perform the contract work but may also increase the costs

for many of the parties involved.

The present study focuses on the following objectives:

(i) Identify factors that significantly contributed to time and costs overruns in Ghadir project;

(ii) Establish the relative importance of these factors;

(iii) Quantify the time and costs associated with the significant factors.

(iv) Finding the solution to decrease delays 


\section{Methodology Used}

Field research based on the author's observations, interviews, formal correspondence, photos, project scheduling, and interview with experienced people, study of the drawings and plans, and the author's perceptions of project management requirements, examined popular causes of delay in this project.

\section{Ghadir project:}

The project is inclusive of 2206 residential units with about 222000-sqm floor area, which should be handed over in about 24 months excluding landscaping. The type of contract was fixed price (2650000 IRR/sqm on the time of agreement $\approx 240 \mathrm{USD} / \mathrm{sqm}$ )

The site location ( $\left.32^{\circ} 31^{\prime} 50.26^{\prime \prime} \mathrm{N}, 51^{\circ} 20^{\prime} 35.96 " \mathrm{E}\right)$ is in Fooladshahr, the new town of Fooladshahr at the central part of Lenjan city, 25 kilometers from the south-west of Isfahan, is located in the communication axis of Isfahan and Shahrecord. The area of this town is over 7700 hectares.

Fooladshahr was established for the residence of Zobe-ahan staff in 1963 and it started its activities from 1984 as a new town. More than 85000 people live in this town at present.

Because of its nearness to the center of the province with an easy access to great industries such as Zobe-ahan, Foolad Mobarakeh, and Sepahan Cement factory, this town is diverted into a suitable location for residence. Other living advantages of this new town are its nearness to higher educational centers such as Isfahan University of Technology, Isfahan University, and Najafabad Azad University.

The general information of Ghadir project is shown in table

\begin{tabular}{|c|c|c|c|c|c|c|c|c|c|c|c|c|}
\hline $\begin{array}{l}\frac{\sigma}{2} \\
\frac{0}{2} \\
\frac{2}{2} \\
\frac{\pi}{2}\end{array}$ & 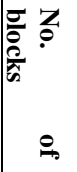 & 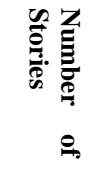 & 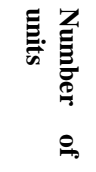 & 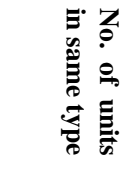 & 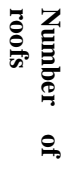 & 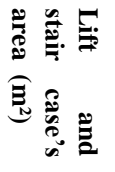 & 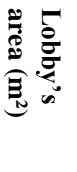 & 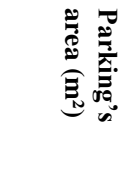 & 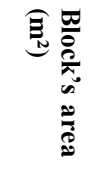 & 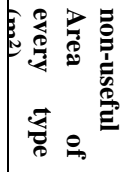 & 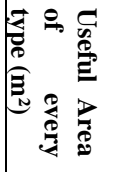 & 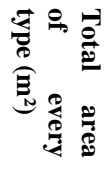 \\
\hline $\mathbf{A}$ & 43 & 4 & 18 & 774 & 5 & 161.05 & 41.2 & 106.7 & 1750 & 13284 & 61966 & 75250 \\
\hline B & 12 & 4 & 26 & 312 & 5 & 388 & 78.1 & 194.67 & 2710 & 7929.7 & 24590 & 32520 \\
\hline $\mathrm{C}$ & 14 & 5 & 22 & 308 & 6 & 132.6 & 32.9 & 362.58 & 2338 & 7393.1 & 25339 & 32732 \\
\hline D & 4 & 5 & 27 & 108 & 6 & 260.4 & 15.3 & 421.23 & 2952 & 2787.6 & 9020 & 11808 \\
\hline $\mathbf{E}$ & 8 & 6 & 38 & 304 & 7 & 456.96 & 72.3 & 235.27 & 3780 & 6116.6 & 24123 & 30240 \\
\hline E-1 & 2 & 8 & 50 & 100 & 9 & 587.52 & 72.3 & 235.27 & 4860 & 1790.3 & 7930 & 9720 \\
\hline $\mathbf{F}$ & 2 & 4 & 18 & 36 & 5 & 155 & 19.7 & 319.5 & 1820 & 988.34 & 4472 & 5460 \\
\hline F-1 & 12 & 5 & 22 & 264 & 6 & 186 & 19.7 & 319.5 & 2186 & 6302 & 17744 & 24046 \\
\hline $\begin{array}{r}\text { Tota } \\
1\end{array}$ & 97 & -------. & & 2206 & --- & 2327.5 & 352 & 2194.7 & 22396 & 46592 & $\begin{array}{l}17518 \\
4\end{array}$ & 221776 \\
\hline
\end{tabular}

Table 1-General information of Ghadir project residential units

\section{Design changes:}

\section{Studies on significant causes of delay}

Design changes and delays in design approval have caused delay to the project.

A number of studies have been carried out to determine the causes of delay in construction projects. Sweis et al. (2008) studied the causes of delay in residential projects in Jordan and concluded that financial difficulties faced by the contractor and too many change orders by the owner are the leading causes of construction delay.

Assaf and Al-Hejji [6] conducted a survey on time performance of large construction projects in Saudi Arabia. The survey had 73 different causes of delay. The researcher studied the importance of various causes from the viewpoint of contractors, consultants, and owners. The most common cause of delay identified by all the parties was "change order". The researcher also found that about $70 \%$ of the projects experienced time overruns.

\subsection{Change in structure system}

Primary design (Insulating concrete formwork system (ICF)) changed to Steel Frame structure system (with steel joist roofing system)

In the Ghadir project, started the execution of some foundations, on 29th march 2010 with ICF methodinsulating concrete formwork-by the contractor (Tak-Ista).

But the main contractor-HESACO-halted the work and changed the plan from ICF to steel structure 


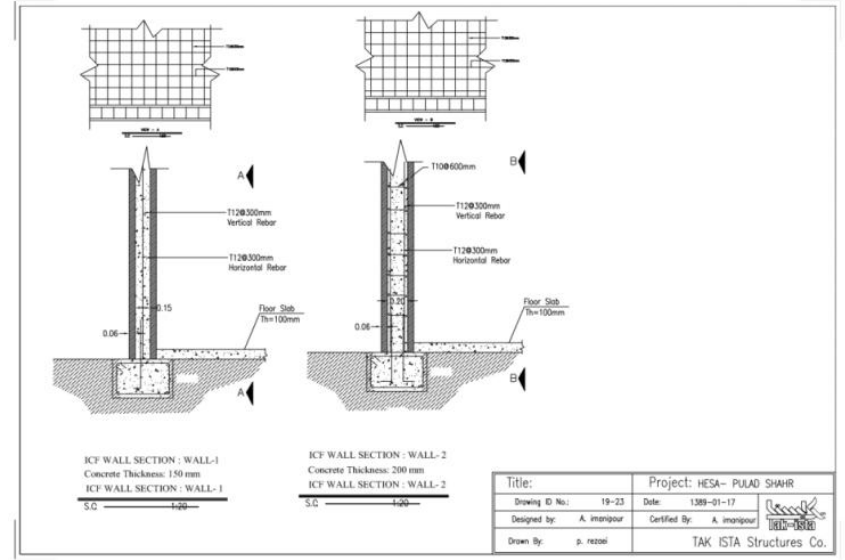

Figure 1-primery typical ICF drawings of Ghadir 2206 residential project

Since the written permission for the various changes were not obtained from the government, they were carried out based on oral discussion with competent authorities.

Because of these changes, the contract between HESACO and contractor (Tak-Ista) revoked whereas they had already done mobilization. All drawings also had to change, causing delays and problems.

Furthermore, seven foundation of hat type (ICF) had been done and they had to be changed and retrofitted for new design. (Figure 1)

\subsection{Change in the type of supports}

The sub-contractor of steel structure's execution, with the coordination and approval of the main contractor changed the type of supports for faster installation.(figure 2 and 3)

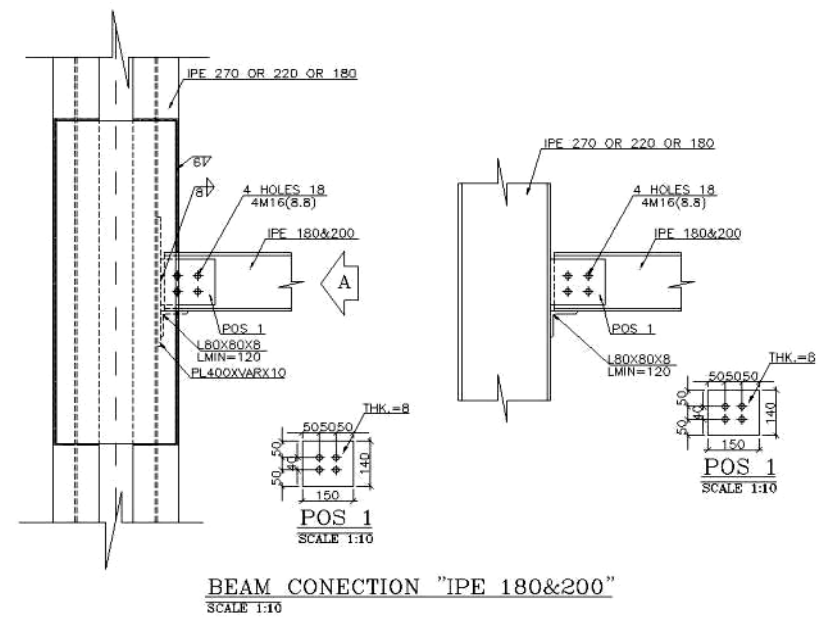

Figure 2 - sample supports of the beams

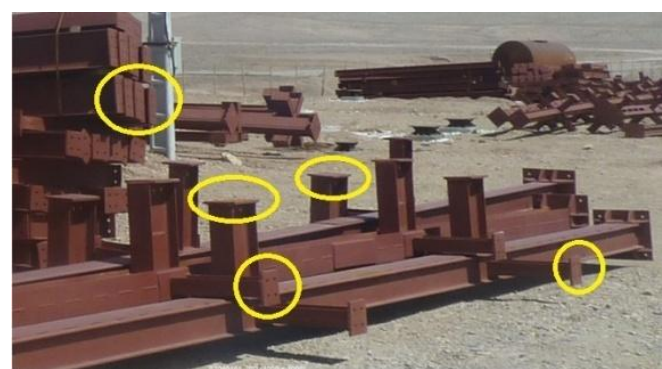

Figure 3 -executed supports of beams.

The executed supports were, fixed support; whereas most of those designed, were hinged support. Supervisors of the project's structure, rejected the work, and sent a non-conformance report to the client. Structural designer ordered that new connections must completely be fixed and two ends of beam must be changed to hinged support (as per design). 
Many beams and columns had been made in wrong shape and company spent a lot of time to correct and rectify the problems.

To do the changed work, at least four plates were required and a large number of labours were added to each beam. Because of this, the project got affected in terms of economy and time.

\subsection{Change in foundation execution level}

Use of pedestal;

Regardless of the designer's idea, contractor's project manager decided to break the height differences in implementation of foundations by two-levels. This decision caused the following:

- The volume of excavation reduced.

- Increase in speed

- Achieved lower cost

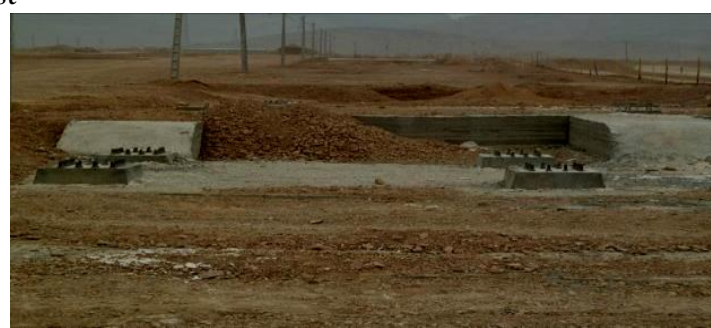

Figure 4 - A two-levels foundation

The Level differences in foundations created disputes between the structural designer and the contractor; the designer did not accept changes in foundations without new calculations. This dispute also arose with the employer and the employer convened some meetings on the employer's office and on-site. Finally, designer did not accept the situation to continue the work, refused to accept responsibility, refused to continue with the process, and finally canceled his contract with contractor.

The Contractor negotiated with another designer and he accepted to prepare a corrective structural design. This design took a significant time of the project.

Finally, the new designer agreed with the composition of same foundations with metal pedestals. Three different types of pedestals $(0 \mathrm{~cm}$ to $50 \mathrm{~cm}$ and from $50 \mathrm{~cm}$ to $100 \mathrm{~cm}$ and from $100 \mathrm{~cm}$ to $150 \mathrm{~cm}$ and relevant reinforcement around each pedestal filled with concrete). Moreover, the specific reinforced concrete wall around the elevator's foundation made around the foundations and framed. (Figure 5a, 5b, 5c)

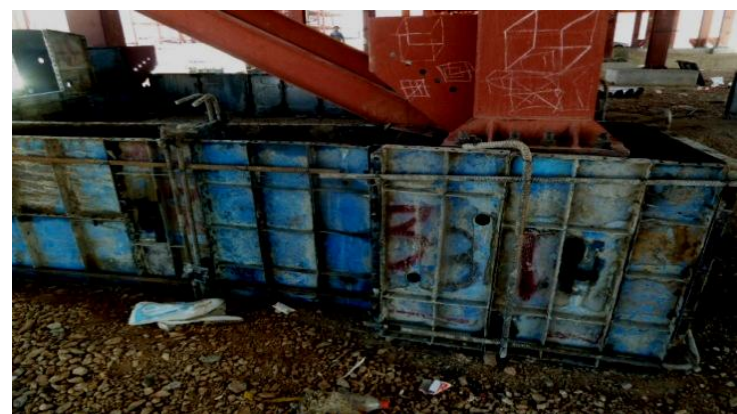

Figure 5a-Special concrete wall around the lift foundation

In approximately all foundations, a large amount of time and cost incurred because of improper level due to a steep slope. These included:

- Drilling time and costs for installation of reinforcements

- Special adhesive reinforcement installation costs

- Reinforcement costs

- Formworking costs

- Additional cost of concreting

- Overhead costs, and the like 


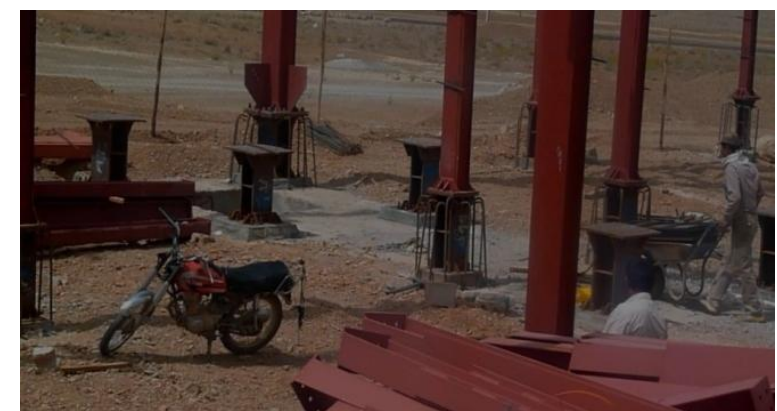

Figure 5b -Steel pedestals

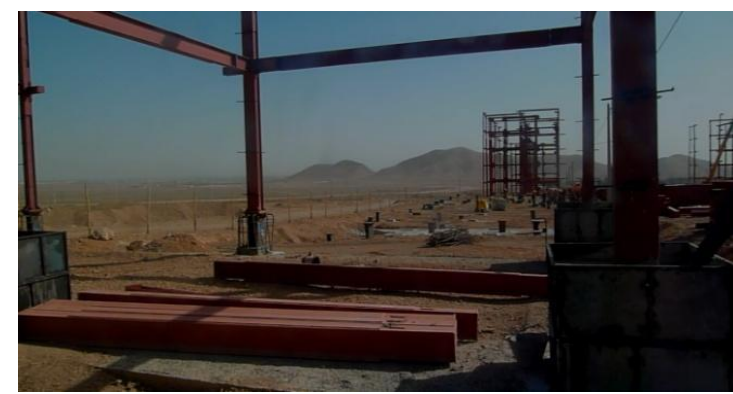

Figure 5c -Many pedestals

The corrective drawings got ready when a large number of structural columns were prepared and how to install a column on pedestal was another problem. The designer's idea was that the pedestal should be built in the factory and carried to project site, then by controlled welding should install the pedestal on base plates and in the next step, by using bolts and nuts, place the column on the pedestal.

This work involved using three base plates instead of one base plate (figure 6).

This decision resulted in increased time and cost.

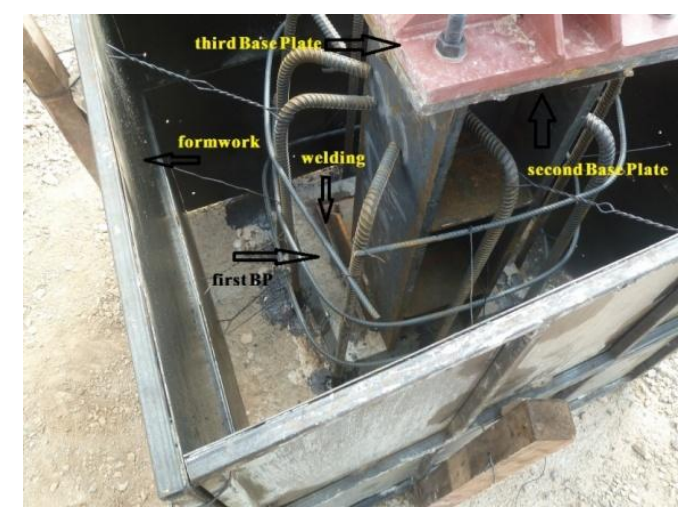

Figure7 - A pedestal before pouring concrete

The total Extra steel that was used for pedestals is more than 200 tonnes. The total extra steel that was used for beam correction is about 20 tonnes.

The total extra steel that used for span correction in the new method of roofing system resulted in 495 tones. The total time that got delayed in this part of the work was more than 6 months.

\section{Material price escalation}

America's sanctions against Iran's nuclear power had led to a decrease in the value of national currency.

Not only this project but also most of the other projects that had a fixed price contract (in private and public sectors) were affected of this cause.

Price of steel and other material and production facilities increased as well as foreign currency rates. 


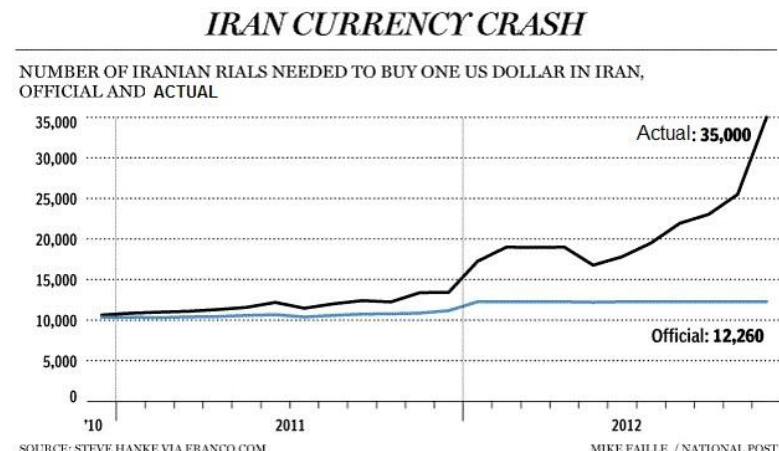

Figure 17-Diagram of the currency rate changes during one year

Senior managers believe the increased prices of all materials that are using in construction works have big losses, COE of HESACO believes: if they wish to continue the project, at least $50 \%$ of the total contract cost is wasteful.

The contractor did not work anymore and contract revoked.

The real price on the time of revocation should be equal to240 USD means $\approx$ $(3500 / 1100) * 240=7,640,000 \mathrm{IRR} / \mathrm{sqm})$ means about 3.18 time more than the time of agreement.

\section{Effect of delay on project:}

Identification of causes and effects alone do not help the project managers to take appropriate remedial or preventive reaction. The project managers need to understand, what factors result in time overrun or cost overrun. When these factors become clear, the managers can take proactive steps to avoid such situations. For example, if it is known that time overruns are predominantly caused by any force majeure or contractor related factors, the project manager can: (1) make sure that payments for the completed work are paid on time, (2) reduce owner interference, (3) speed up the decision-making process, and (4) avoid unrealistic contract duration and requirements. Therefore, the link between causes and effects of delays need to be established.

In case of delay common effects are (1) time overrun, (2) cost overrun, (3) disputes, (4) arbitration, (5) litigation, and (6) total abandonment

\section{Prescription to reduce delay:}

1. In case of design changes, contractors must study all the drawings Very carefully before doing anything.

2. If contractor started the work and faced with wrong in drawings, must immediately inform the consultant engineer and client for start to correct the designs and contractor should consider the delay time in project schedule.

3. Sanction and unbelievable price escalation in fixed price contracts can be considered as a force majeure situation.

\section{Conclusions}

This paper investigated the causes and effects of delays facing in the Ghadir 2206 residential units. Based on Field research collected the information and I identified main causes of delay and ten most important causes were:

1) Contractor's improper planning, 2) Design changes, 3) Contractor's poor site management and mistaken decision in change managers, 4) Inadequate contractor experience, 5) Inadequate client's finance and payments for completed work, 6) Problems with subcontractors, 7) Lack of communication between parties, 8) Construction Mistakes and Defective Works ,9) Sanction.

I identified main effects of delay and they were: (1) time overrun, (2) cost overrun, (3) disputes, (4) arbitration, (5) litigation, and (6) total abandonment.

Researcher believes that the results of this study can be of immense help to the related parts (clients, contractors, and consultants) in future projects and academicians. The practitioners can better understand the dynamics of project management and make efforts to reduce the incidences of delays. The academicians can conduct similar studies in other parts of world and identify causes and effects of delays. As mentioned earlier, some causes and effects may be unique to certain countries. 


\section{References}

[1]. Agyakwah-Baah, Frank D.K. Fugar and Adwoa B. "Delays in Building Construction Projects in Ghana." Australasian Journal of Construction Economics and Building, (2010)10 (1/2): 103-116.

[2]. Andersson; Claes-Axel;et al. Site management handbook. Geneva: International Labour Office, 1996.

[3]. Assaf, S.A. AlHejji S. "Causes of delay in large construction projects." International Journal of Project Management, , (2006)24 (4): 349-357.

[4]. Murali Sambasivan, Yau Wen Soon. "Causes and effects of delays in Malaysian construction industry." International Journal of Project Management, (2007) 27: 517-526.

[5]. Sweis, G., Sweis, R., Abu Hammad, A. and Shboul, A. "Delays in construction projects: The case of Jordan." International Journal of Project Management, (2008)26 (6): 65-74.

[6]. T, Barry B. Bramble and Michael. Construction Delay Claims. Wolters Kluwer Law \& Business, 2010.

[7]. Z, Prosci. web page:Change Management Pilot Professional. http://www.change-management.com/cm-pilot.htm

[8]. Ziabari, Kourosh. web page:Iran Hyperinflation. http://www.marketoracle.co.uk/Article37225.html.

[9]. websit of municipality, Fooladshahr. web page :about Fooladshahr. http://www.fooladshahr.ir/web/fooladshahren/fooladshahr 